\title{
PENGARUH PROFITABILITAS, LEVERAGE, UKURAN PERUSAHAAN DAN RISIKO BISNIS TERHADAP KEBIJAKAN DIVIDEN PADA PERUSAHAAN MANUFAKTUR
}

\author{
Tresna Dewi Mnune ${ }^{1}$ \\ Ida Bagus Anom Purbawangsa ${ }^{2}$
}

\author{
${ }^{1,2}$ Fakultas Ekonomi Dan Bisnis Universitas Udayana (Unud), Bali, Indonesia \\ e-mail: mnunetresna@yahoo.com
}

\begin{abstract}
ABSTRAK
Kebijakan dividen berkaitan dengan pengalokasian dan pendistribusian laba yang dimiliki perusahaan. Kebijakan dividen merupakan salah satu dari keputusan keuangan yang berhubungan dengan kebijakan apakah laba yang didapatkan perusahaan akan dibayarkan kepada pemegang saham dalam bentuk dividen atau ditahan guna memperkuat struktur modal. Penelitian ini mencoba menjelaskan mengenai pengaruh beberapa variabel yakni profitabilitas, leverage, ukuran perusahaan dan risiko bisnis. Sampel dalam penelitian ini adalah enam perusahaan manufaktur yang terdaftar di Bursa Efek Indonesia periode 20132017. Teknik analisis data dalam penelitian ini menggunakan regresi linier berganda. Hasil penelitian menunjukkan bahwa profitabilitas secara positif signifikan mempengaruhi kebijakan dividen, leverage secara positif signifikan mempengaruhi kebijakan dividen, ukuran perusahaan tidak mempengaruhi kebijakan dividen, serta risiko bisnis secara negatif signifikan mempengaruhi kebijakan dividen. Implikasi penelitian ini diharapkan mampu memberikan pertimbangan dalam mengambil keputusan baik kepada perusahaan maupun pemegang saham terkait faktor yang mempengaruhi kebijakan dividen.
\end{abstract}

Kata kunci: profitabilitas, leverage, ukuran perusahaan, risiko bisnis, kebijakan dividen

\begin{abstract}
Dividend policy is related to allocation and distribution of company profits. Dividend policy is one of the financial decisions related to the policy of whether the company's profits will be paid to shareholders as dividends or retained to strengthen the capital structure. This study aimed to examine the effect on profitability, leverage, firm size and business risk to dividend policy of the company in Indonesia Stock Exchange period 20132017. The sample used in this study were 6 manufacturing companies listed in Indonesia Stock Exchange from the period 2013-2017 Data analysis techniques in this study uses multiple linear regression. The results show that profitability has a positive and significant effect on dividend policy, leverage has a positive and significant effect on dividend policy, firm size has a negatif and not significant effect on dividend policy and business risk has a negatif and significant effect on dividend policy. The implications of this study are expected to give consideration in making decisions by companies and shareholders about dividend policy.

Keywords :profitability, leverage, firm size, business risk, dividend policy
\end{abstract}




\section{PENDAHULUAN}

Perusahaan memiliki empat fungsi utama yakni pemasaran, keuangan, sumber daya manusia dan operasional. Perusahaan memerlukan aset untuk membiayai seluruh kegiatan operasional perusahaan. Aset perusahaan harus dikelola dengan baik sehingga perusahaan mampu mencapai tujuannya. Hal ini menyebabkan perusahaan membutuhkan manajemen keuangan untuk mnegelola seluruh aset yang dimiliki oleh perusahaan sehingga nantinya tujuan perusahaan dapat tercapai (Husnan dan Pudjiastuti, 2012: 3).

Manajemen keuangan memiliki tiga bentuk keputusan utama, yakni keputusan dalam hal investasi, keputusan yang berkaitan dengan pendanaan dan kebijakan dividen. Berdasarkan ketiga keputusan manajemen keuangan, keputusan yang terakhir yaitu kebijakan dividen merupakan keputusan yang paling rumit dilakukan oleh perusahaan. Kebijakan dividen (Dividen Payout) yakni aktivitas pendistribusian laba yang didapatkan perusahaan (Sartono, 2010: 281).

Penelitian ini menggunakan empat faktor yang mempengaruhi kebijakan pembayaran dividen yaitu profitabilitas, leverage, ukuran perusahaan dan risiko bisnis. Keempat faktor ini dipilih sebagai variabel karena terdapat research gap pada penelitian sebelumnya.

Profitabilitas didefinisikan sebagai kemampuan perusahaan dalam memperoleh laba dengan penjualan, total aktiva maupun modal sendiri (Sugiyarso dan Winarni, 2005: 118). Tingkat profitabilitas yang dimiliki oleh perusahaan 
Tresna Dewi Mnune dan Ida Bagus Anom Purbawangsa, Pengaruh Profitabilitas....

memberikan dampak besaran dividen yang dibagikan kepada pemegang saham. Hasil penelitian yang dilakukan oleh Forti et al. (2015), Khan et al. (2013) danMalik et al. (2013)menemukan bahwa profitabilitas secara positif signifikan mempengaruhi kebijakan dividen. Namun terdapat hasil penelitian berbeda yang ditemukan oleh Gusni (2017),Kaźmierska-Jóźwiak (2015) danOsegbue et al. (2014) menemukan bahwa profitabilitas secara negatif signifikan mempengaruhi kebijakan dividen.

Faktor kedua yaitu leverage. Leverage diartikan sebagai kemampuan perusahaan dalam memenuhi kewajiban keuangannya dan mengukur sejauh mana perusahaan menggunakan hutang untuk membiayai operasional perusahaan (Husnan dan Pudjiastuti, 2012: 72). Hasil penelitian dari peneliti sebelumnya yaitu Awad (2015), Odawo \& Ntoiti (2015) dan Osegbue et al. (2014) menemukan bahwa leverage secara positif signifikan mempenagruhi kebijakan dividen. Namun penelitian yang dilakukan oleh Asad \& Yousaf, (2014), Forti et al. (2015), dan Khan \& Ashraf (2014) menemukan bahwa leverage berpengaruh negatif pada kebijakan dividen.

Ukuran perusahaan juga menjadi salah satu faktor pertimbangan dalam pembayaran dividen. Ukuran perusahaan memberikan cerminan kondisi perusahaan yang diukur dari total aset perusahaan. Struktur keuangan internal menjadi indikator penentuan ukuran perusahaan. Perusahaan dengan struktur keuangan internal yang kuat dilihat dari total aset besar digolongkan sebagai perusahaan besar sedangkan perusahaan dengan total aset kecil digolongkan sebagai perusahaan kecil (Devi \& Erawati, 2014). Hasil penelitian yang dilakukan 
oleh Yusof \& Ismail (2016), Kaźmierska-Jóźwiak (2015), Awad (2015), Asad \&Yousaf (2014), Forti et al. (2015),Komrattanapanya \& Suntraruk (2014) danAlkhadhiri (2013) menemukan bahwa ukuran perusahaan secara positif signifikan mempengaruhi kebijakan dividen. Namun penelitian Iswara (2017), Nidya \& Titik (2015) dan Dada et al. (2015) menemukan bahwa ukuran perusahaan secara negatif signifikan mempengaruhi kebijakan dividen

Faktor keempat yaitu risiko bisnis. Risiko merupakan suatu kondisi yang memungkinkan munculnya kerugian (Gitosudarmo dan Basri, 2008:16). Risiko bisnis diartikan sebagai suatu kondisi ketidakamanan keuangan yang berdampak pada penurunan kinerja perusahaan. Hasil penelitian yang dilakukan oleh Ahmad dkk. (2016), Demirgünescedil (2015), Maldajian \& El Khoury (2014) dan Amah (2012) menyatakan bahwa risiko bisnis berpengaruh positif dan signifikan terhadap kebijakan dividen. Namun hal ini berbeda dengan penelitian yang dilakukan oleh Osegbue et al. (2014), Forti et al. (2015) dan Al-khadhiri (2013) yang menyatakan bahwa risiko bisnis secara negatif signifikan mempengaruhi kebijakan dividen.

Penulis menjadikan sektor manufaktur yang terdaftar di Bursa Efek Indonesia (BEI) sebagai subjek penelitian karena sektor manufaktur tetap menjadi sector unggulan pada tahun 2018 karena banyaknya investor yang menanamkan dananya pada sektor ini sehingga mampu menciptakan multiplier effect yang berdampak pada peningkatan ekonomi. Berdasarkan adanya kontroversi pengaruh variabel profitabilitas, leverage, ukuran perusahaan dan risiko bisnis terhadap 
Tresna Dewi Mnune dan Ida Bagus Anom Purbawangsa, Pengaruh Profitabilitas....

kebijakan dividen maka menarik untuk dikaji ulang serta memperjelas hubungan antara variabel tersebut dengan kebijakan dividen.

Permasalahan yang akan dibahas pada penelitian ini adalah 1) Apakah profitabilitas berpengaruh signifikan terhadap kebijakan dividen? 2) Apakah leverage berpengaruh signifikan terhadap kebijakan dividen? 3) Apakah ukuran perusahaan berpengaruh signifikan terhadap kebijakan dividen? 4) Apakah risiko bisnis berpengaruh signifikan terhadap kebijakan dividen?. Berdasarkan rumusan masalah yang telah diuraikan, maka tujuan penelitian ini adalah sebagai berikut: 1) Untuk menguji signifikansi pengaruh profitabilitas terhadap kebijkan dividen. 2) Untuk menguji signifikansi pengaruh leverage terhadap kebijkan dividen. 3) Untuk menguji signifikansi pengaruh ukuran perusahaan terhadap kebijkan dividen. 4) Untuk menguji signifikansi pengaruh risiko bisnis terhadap kebijkan dividen pada perusahaan. tujuan penelitian sejalan dengan rumusan masalah. Penelitian ini diharapkan mampu memberikan bukti empiris mengenai pengaruh variabel bebas penelitian yakni profitabilitas, leverage, ukuran perusahaan dan risiko bisnis terhadap kebijakan dividen serta memberikan pertimbangan terkait pengambilan kebijakan dividen bagi perusahaan maupun pemegang saham.

Agency theory merupakan teori mengenai keterkaitan antara pemegang saham (principal) dan manajemen perusahaan (agen). Keterkaitan kewenangan antara pemegang saham dan manajemen perusahaan terjadi dimana pemegang saham sebagai pemilik perusahaan menyerahkan kewenangan kepada manajemen sebagai tenaga profesional untuk mengelola perusahaan (Putri dan Ulupui, 2017: 23). Penyerahan kewenangan dalam pengelolaan perusahaan dari pemegang 
saham ke manajemen menimbulkan adanya asimetri informasi. Asimetri informasi yang dimaksud yakni adanya perbedaan pengetahuan informasi terkait perusahaan antara manajemen dan pemegang saham, dimana pemegang saham memiliki informasi terkait perusahaan lebih sedikit dibandingkan manajemen. Manajemen dan pemegang saham memiliki kepentingan masing-masing sehingga memicu kurangnya keterbukaan dari manajemen kepada pemegang saham yang menimbulkan agency conflict (Sartono, 2010: 10). Agency conflict dapat diminimalisir dengan pembayaran dividen. Pembayaran dividen dapat memberikan keyakinan kepada pemegang saham bahwa perusahaan telah dikelola dengan baik oleh manajemen sehingga mampu memaksimalkan kekayaan pemegang saham.

Wiagustini (2014: 8) mendefinisikan kebijakan dividen merupakan salah satu dari keputusan keuangan yang berhubungan dengan kebijakan apakah laba yang didapatkan perusahaan akan dibayarkan kepada pemegang saham dalam bentuk dividen atau ditahan guna memperkuat struktur modal. Van Horne and Wachowicz (2012: 270) menyatakan bahwa hal utama dari kebijakan dividen adalah menentukan pengalokasian laba yang tepat antara pembayaran dividen dengan laba ditahan perusahaan. Persentase dividen yang dibagikan kepada pemegang saham berubah seiring berjalannya waktu mengikuti perubahan peluang penanaman dana yang dapat diterima dan tersedia bagi perusahaan. Jika peluang investasi perusahaan tinggi maka dividen yang dibayarkan cenderung nol, sedangkan jika perusahaan tidak menemukan peluang investasi maka dividen akan 
Tresna Dewi Mnune dan Ida Bagus Anom Purbawangsa, Pengaruh Profitabilitas....

dibayarkan $100 \%$ dari laba. Hal ini menunjukkan bahwa kebijakan dividen perlu mempertimbangkan keputusan pendanaan dan investasi.

Brigham dan Houston (2011: 211) menyatakan bahwa terdapat beberapa teori tentang kebijakan dividen. Pertama, Dividend Irrelevance Theory yang dikemukakan oleh Miller dan Mondigliani (MM) berpendapat bahwa saat perusahaan memiliki peluang investasi maka pembayaran dividen tidak mempengaruhi kekayaan pemegang saham. MM memiliki sebuah asumsi penting yang menyatakan bahwa kebijakan investasi perusahaan tidak memiliki keterkaitan dengan kebijakan dividennya. Jika perusahaan memiliki kebijakan terkait investasi maka kebijakan dividen hanya akan mempengaruhi besar kecilnya pendanaan dari luar (disamping dana dari laba ditahan) yang dibutuhkan untuk mendanai investasi baru dan membayar dividen. Hal ini berarti bahwa setiap kenaikan satu satuan pembayaran dividen mencerminkan adanya kerugian satu satuan dalam suatu investasi. Dampak penting dari adanya teori ini yakni sebaiknya perusahaan mengutamakan terlebih dahulu kebijakan investasi dibandingkan kebijakan dividen.

Teori kebijakan dividen yang kedua yakni Bird In The Hand Theory. Teori ini dikemukakan oleh Gordon dan Lintner yang menyatakan bahwa pemegang saham lebih menyukai burung ditangan atau kepastian (bird in the hand) dalam bentuk dividen tunai dibandingkan dengan keuntungan yang belum pasti (bird in the bush) yaitu selisih positif harga saham yang menghasilkan capital gain. Menaikkkan pembayaran dividen saat hal-hal lain dianggap konstan akan dapat menaikkan nilai perusahaan. Hal ini disebabkan karena dividen yang diberikan 
saat ini dapat mengurangi biaya modal sehingga akan menaikkan nilai perusahaan. Jadi rasio pembayaran dividen yang tinggi akan memaksimalkan nilai perusahaan. Ketiga yaitu tax differential theory. Tax differential theory dikemukakan oleh Lizenberger dan Ramaswamy (1979) yang menyatakan bahwa pendapatan yang sesuai bagi pemegang saham adalah pendapatan setelah pajak sehingga keuntungan yang diharapkan juga setelah pajak. Teori ini mengungkapkan bahwa pemegang saham lebih menyukai capital gain yang tinggi dibandingkan dividen yang tinggi. Pemegang saham mengharapkan perusahaan untuk menahan laba setelah pajak dan menggunakannya untuk membiayai investasi lain yang lebih menguntungkan dibandingkan melakukan pembayaran dividen. hal ini akan mengurangi jumlah pajak yang dikenakan kepada pemegang saham sehingga pendapatan yang diterima akan lebih besar.

Teori yang keempat yaitu Signalling Theory. Teori ini menyatakan bahwa pembayaran dividen dapat memberikan sinyal positif ke pasar bahwa kinerja baik dan penurunan dividen menunjukkan kinerja perusahaan yang buruk. Teori ini dapat menjawab pertanyaan mengapa perusahaan membayarkan dividen yang disesuaikan dengan laba bersih. Perubahan pembayaran dividen mengandung informasi yang mampu menimbulkan perubahan persepsi pemegang saham terkait prospek perusahaan kedepannya yang berdampak pada penyesuaian harga saham saat tejadi perubahan dividen diumumkan. Namun demikian, peningkatan dividen dapat pula menjadi sinyal negatif bagi investor. Perusahaan yang meningkatkan pembayaran dividen dapat dianggap sebagai perusahaan yang memiliki prospek yang buruk kedepannya. Hal ini dapat terjadi karena pada dasarnya perusahaan 
Tresna Dewi Mnune dan Ida Bagus Anom Purbawangsa, Pengaruh Profitabilitas....

membayarkan dividen yang tinggi saat kebutuhan investasi rendah atau bahkan nol. Perusahaan dengan tingkat investasi yang rendah akan dinilai oleh sebagian pemegang saham sebagai ketidakmampuan perusahaan untuk mengembangkan usaha dan tidak adanya investasi yang prospektif di masa depan. Oleh sebab itu perusahaan harus berhati-hati dalam memutuskan berapa jumlah pembayaran dividen yang tepat kepada pemegang saham sehingga nantinya mampu menghasilkan suatu dampak baik bagi perusahaan ke depannya.

Teori yang terakhir yaitu Clientele Effect. Teori ini menjelaskan mengenai kondisi pada suatu perusahaan yang terdapat banyak kelompok pemegang saham dengan berbagai kepentingan yang menimbulkan pertentangan. Pertentangan ini timbul sebagai akibat dari adanya pemegang saham yang menyukai memperoleh pendapatan saat ini dalam bentuk dividen dan pemegang saham yang lebih suka melakukan reinvestasi karena dikenakan pajak yang cukup tinggi. Saat perusahaan memutuskan untuk menahan laba setelah pajak, maka pemegang saham yang menyukai pembayaran dividen akan kecewa. Sementara pemegang saham yang memilih reinvestasi menghendaki perusahaan membayar dividen yang rendah karena pembayan dividen yang besar menimbulkan pajak yang dibayarkan juga besar. Hal ini terjadi karena setiap kenaikan pembayaran dividen menyebabkan kenaikan pada pajak yang harus dibayar pemegang saham. Kenaikan pajak ini menyebabkan pembayaran dividen tidak begitu menguntungkan.

Perbedaan kepentingan ini menimbulkan dampak klien yang artinya perusahaan mempunyai klien yang berbeda-beda dimana setiap klien memiliki preferensi yang berlainan. Hal ini menyebabkan kebijakan dividen yang diambil 
perusahaan akan mengecewakaan beberapa klien yang berdampak negatif pada harga saham. Oleh sebab itu perusahaan harus berusaha untuk menstabilkan kebijakan dividen agar klien pada perusahaan tidak terganggu.

Profitabilitas didefinisikan sebagai usaha perusahaan untuk memperoleh laba melalui semua sumber daya yang dimiliki dan ukuran efektivitas manajemen suatu perusahaan (Harahap, 2013: 364). Profitabilitas perusahaan dinilai dari modal sendiri atau keseluruhan dana yang terdapat pada perusahaan (Raipassa dkk., 2015). Profitabilitas memberikan penilaian secara keseluruhan terkait kinerja perusahaan. Profitabilitas mengukur seberapa tingkatan pengembalian yang diharapkan dari investasi yang dilakukan pemegang saham. Apabila keadaan perusahaan tergolong menguntungkan dimasa depan maka akan meningkatkan keinginan pemegang saham untuk membeli saham perusahaan tersebut (Sudana, 2011: 167).

Subramanyam dan Wild (2010: 265) menyatakan leverage sebagai usaha untuk memenuhi kewajiban keuangan yang dilakukan perusahaan serta berkaitan dengan penggunaan hutang dalam struktur modal. Perusahaan yang tidak memiliki leverage berarti seluruh biaya operasional yang terdapat pada perusahaan menggunakan modal sendiri. Penggunaan leverage menyebabkan tiga dampak penting yaitu pertama, perusahaan dapat dikendalikan oleh pemegang saham. Kedua, ekuitas dijadikan sebagai batas pengaman oleh kreditur. Dampak penting ketiga yaitu pemanfaatan leverage mampu meningkatkan pengembalian modal. Hal ini dapat terjadi apabila aktiva perusahaan lebih tinggi dari bunga (Brigham and Houston, 2011: 164). 
Tresna Dewi Mnune dan Ida Bagus Anom Purbawangsa, Pengaruh Profitabilitas....

Penggunaan hutang yang meningkat mampu memberikan manfaat positif bagi perusahaan, namun jika pemanfaatan leverage berada lebih besar dari manfaat yang diperoleh maka penggunaan leverage harus dihentikan. Efektivitas penggunaan utang nantinya mampu meningkatkan laba perusahaan yang berdampak pada meningkatnya kemampuan perusahaan untuk membagikan dividen kepada pemegang saham.

Ukuran perusahaan mencerminkan total aktiva, nilai pasar saham, tingkat penjualan suatu perusahaan (Brigham and Houston, 2011: 40). Penelitian ini menggunakan total aktiva sebagai indikator penilaian ukuran perusahaan. Total aktiva merupakan aset perusahaan yang digunakan untuk membiayai operasional perusahaan. Perusahaan dengan total aktiva besar mengindikasikan bahwa perusahaan memiliki struktur keuangan yang kuat dengan arus kas positif. Hal ini memberikan keyakinan bahwa dimasa depan perusahaan memiliki prospek yang baik (Arjana \& Suputra, 2017).

Risiko merupakan suatu kondisi yang memungkinkan munculnya kerugian (Gitosudarmo dan Basri, 2008:16). Risiko bisnis merupakan risiko dalam menjalankan kegiatan bisnis (Tandelilin, 2010: 104). Risiko bisnis merupakan fluktuasi ketidakpastian yang menyebabkan perusahaan mengalami kesulitan untuk beroperasi dan ketidakamanan keuangan perusahaan.

Suatu perusahaan akan selalu berusaha meningkatkan citranya melalui peningkatan laba yang akan berdampak pada kenaikan jumlah laba yang dibayarkan kepada pemegang saham sebagai pembayaran dividen. Hal ini akan memicu terjadinya kenaikan harga saham perusahaan karena dengan 
mengumumkan adanya peningkatan dividen, maka pemegang saham ataupun calon pemegang saham akan menganggap kondisi perusahaan saat ini dan di masa mendatang memiliki prospek yang baik sesuai dengan signaling theory. Perusahaan yang mampu membayarkan dividen mengindikasikan bahwa perusahaan memiliki pendapatan serta free cash flow yang baik (Safrida, 2014). Penelitian yang dilakukan oleh Thaib \& Taroreh (2015), Fillya dkk. (2015), Hossain et al. (2014), Prawira dkk. (2014), Khan et al. (2013) dan Malik et al. (2013)menemukan bahwa profitabilitas secara positif signifikan mempengaruhi pembayaran dividen. Oleh sebab itu hipotesis penelitian yang diajukan yakni:

$\mathrm{H}_{1}$ : profitabilitas berpengaruh positif dan signifikan terhadap kebijakan dividen

Peningkatan terhadap leverage menunjukkan modal usaha menggunakan lebih banyak hutang dibanding modal sendiri. Pembagian dividen mengandung suatu sinyal terkait prospek perusahaan kedepannyan sesuai dengan signaling theory. Perusahaan yang menurunkan dividen saat ketersediaan dana internal menurun akan dinilai oleh pemegang saham sebagai informasi bahwa keadaan perusahaan akan menurun kedepannya. Penggunaan leverage dapat menjadi suatu pilihan yang baik saat ketersediaan dana internal perusahaan untuk membayar dividen tidak mencukupi sehingga perusahaan tidak menurunkan jumlah dividen guna menstabilkan jumlah pembayaran dividen. Awad (2015), Odawo \& Ntoiti (2015) dan Osegbue et al. (2014) menemukan bahwa leverage secara positif signifikan mempengaruhi kebijakan dividen. Oleh sebab itu hipotesis penelitian yang diajukan yakni:

$\mathrm{H}_{2}$ : leverage berpengaruh positif dan signifikan terhadap kebijakan dividen 
Tresna Dewi Mnune dan Ida Bagus Anom Purbawangsa, Pengaruh Profitabilitas....

Perusahaan besar mempunyai peluang investasi tinggi serta kemampuan memperoleh pinjaman saat terjadi kesulitan dalam pendaaan internal. Ukuran perusahaan juga menggambarkan kondisi keuangan perusahaan yang kokoh dengan pengeloaan usaha yang efektif. Besarnya ukuran perusahaan mengindikasikan kestabilan keuangan dan kemampuan menghasilkan keuntungan (Setiawati \& Yesica, 2014). Hal ini yang kemudian dapat dimanfaatkan oleh perusahaan dalam meningkatkan jumlah dividen kepada pemegang saham sehingga ukuran perusahaan menjadi sinyal mengenai prospek perusahaan kedepannya bagi pemegang saham serta kreditur sesuai dengan signaling theory. Yusof \& Ismail (2016), Kaźmierska-Jóźwiak (2015), Awad (2015), Asad \& Yousaf (2014), Forti et al. (2015),Komrattanapanya \& Suntraruk (2014) danAlkhadhiri (2013) menyatakan bahwa ukuran perusahaan secara positif signifikan mempengaruhi kebijakan dividen. Oleh sebab itu hipotesis penelitian yang diajukan yakni:

$\mathrm{H}_{3}$ : ukuran perusahaan berpengaruh positif dan signifikan terhadap kebijakan dividen

Risiko bisnis yang tinggi dapat diartikan sebagai kemungkinan ketidakmampuan dalam membiayai operasional perusahaan yang akan menyebabkan laba menurun. Perusahaan dengan risiko bisnis tinggi berusaha untuk menguatkan stuktur modal sehingga laba yang dimiliki ditahan yang berdampak pada penurunan dividen yang dibayarkan kepada pemegang saham (Epayanti \& Yadnya, 2014). Hal ini membuat perusahaan berusaha untuk mempertahankan laba dalam bentuk laba ditahan sebagai sumber pendanaan internal. Osegbue, et al. (2014), Forti et al. (2015) dan Al-khadhiri (2013) 
menemukan bahwa secara negatif signifikan mempengaruhi kebijakan dividen. Oleh sebab itu hipotesis penelitian yang diajukan yakni:

$\mathrm{H}_{4}$ : risiko bisnis berpengaruh negatif dan signifikan terhadap kebijakan dividen

\section{METODE PENELITIAN}

Penelitian mengenai kebijakan dividen menggunakan pendekatan kuantitatif bersifat asosiatif dengan tujuan mengetahui keterkaitan variabel penelitian (Sugiyono, 2017: 9). Penelitian dilakukan pada perusahaan manufaktur yang terdaftar di BEI periode 2013-2017. Data penelitian diperoleh melalui situs resmi www.idx.com dengan bentuk laporan keuangan. Obyek pada penelitian adalah kebijakan dividen perusahaan manufaktur yang terdaftar di BEI periode 2013-2017. Variabel terikat (Y) yaitu kebijakan dividen sementara variabel bebas $(\mathrm{Xi})$ yaitu Profitabilitas $\left(\mathrm{X}_{1}\right)$, Leverage $\left(\mathrm{X}_{2}\right)$, Ukuran perusahaan $\left(\mathrm{X}_{3}\right)$, dan Risiko bisnis $\left(\mathrm{X}_{4}\right)$.

Kebijakan dividen pada diukur dengan dividend payout ratio (DPR). Alasan penggunaan DPR pada pengukuran kebijakan dividen karena DPR menyatakan persentase jumlah pendapatan kas yang diterima pemegang saham. Satuan DPR yang digunakan pada penelitian ini adalah persen. Secara matematis DPR perusahaan manufaktur yang terdaftar di BEI periode 2013-2017 dapat dirumuskan sebagai berikut:

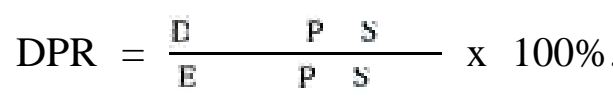


Tresna Dewi Mnune dan Ida Bagus Anom Purbawangsa, Pengaruh Profitabilitas....

Profitabilitas penelitian diukur menggunakan Return on Aset (ROA). Alasan penggunaan ROA pada pengukuran profitabilitas karena ROA merupakan pengukuran yang bersifat menyeluruh. Satuan ROA yang digunakan pada penelitian ini adalah persen. Secara matematis ROA perusahaan manufaktur yang terdaftar di Bursa Efek Indonesia periode 2013-2017 dapat dirumuskan sebagai berikut:

$$
\mathrm{ROA}=\frac{E}{T \quad A} \times 100 \%
$$

Leverage diukur menggunakan Debt to Equity Ratio (DER). Alasan DER sebagai pengukuran leverage karena DER memberikan cerminan penggunaan hutang dalam membiayai kegiatan operasional perusahaan. Satuan DER yang digunakan pada penelitian ini adalah persen.Secara matematis DER perusahaan manufaktur yang terdaftar di BEI periode 2013-2017 dapat dirumuskan sebagai berikut:

$$
\mathrm{DER}=\frac{T \quad H}{\mu \quad n M \quad S} \times 100 \%
$$

Ukuran perusahaan diukur dengan logaritma natural (Ln) dari total aktiva. Total aktiva digunakan sebagai pengukuran pada variabel ukuran perusahaan dengan pertimbangan bahwa nilai dari aktiva lebih stabil jika dibandingkan dengan indikator penilaian lainnya. Satuan ukuran perusahaan adalah rupiah. Ukuran perusahaan pada perusahaan manufaktur yang terdaftar di BEI periode 2013-2017 diukur dengan menggunakan rumus:

Ukuran perusahaan $=$ Ln $($ Total Aktiva $)$ 
Risiko bisnis (BRISK) diukur dengan standar deviasi dari EBIT dibagi total aset. Satuan BRISK adalah persen. Risiko bisnis pada perusahaan manufaktur yang terdaftar di BEI periode 2013-2017 dihitung menggunakan rumus:

BRISK $\quad=\quad \frac{0 \mathrm{E}}{T A}$
$100 \%$

Data kuantitatif penelitian yaitu laporan keuangan perusahaan manufaktur yang terdaftar pada BEI perode 2013-2017. Data kualitatif yaitu daftar perusahaan manufaktur serta gambaran umum perusahaan manufaktur yang terdaftar pada BEI perode 2013-2017. Data sekunder yang digunakan adalah publikasi laporan keuangan DPR, ROA, DER, Total Aktiva, dan EBIT pada perusahaan manufaktur yang terdaftar pada BEI perode 2013-2017 melalui situs resmi www.idx.com.

Populasi pada penelitian ini adalah 161 perusahaan manufaktur yang terdaftar di BEI. Penentuan sampel menggunakan metode purposive sampling sehingga dari 161 perusahaan manufaktur yang terdaftar di BEI periode 20132017 sebagai populasi hanya enam perusahaan yang sesuai dijadikan sebagai sampel penelitian.

Analisis data pada penelitian ini menggunakan teknik regresi linier berganda. Persamaan regresi linier berganda dapat dinyatakan sebagai berikut:

$$
\left.\mathrm{Yt}=\beta_{1} \mathrm{X}_{1}+\beta_{2} \mathrm{X}_{2}+\beta_{3} \mathrm{X}_{3}+\beta_{3} \mathrm{X}_{4}+e\right)
$$

Selain itu terdapat pengujian lainnya yaitu koefisien determinasi, Uji F dan uji t. Sebelum dilakukan analisis regresi linear berganda dilakukan pengujian asumsi klasik untuk meyakinkan bahwa model regresi penelitian berdistribusi normal, dan terbebas dari multikolinearitas, autokorelasi dan heteroskedastisitas. 


\section{HASIL DAN PEMBAHASAN}

Deskripsi variabel penelitian memberikan informasi terkait karakteristik masing-masing variabel penelitian melalui statistika deskriptif. Hasil statistika deskriptif masing-masing variabel ditunjukkan pada tabel 1.

Tabel 1.

Hasil Statistika Deskriptif

\begin{tabular}{|c|c|c|c|c|c|c|}
\hline & & DPR & ROA & DER & $\begin{array}{l}\text { Ln (Tota) } \\
\text { Aktiva) }\end{array}$ & BRISK \\
\hline \multirow[t]{2}{*}{$\mathrm{N}$} & Valid & 30 & 30 & 30 & 30 & 30 \\
\hline & Missing & 0 & 0 & 0 & 0 & 0 \\
\hline Mean & & 55,633 & 21,034 & 1,049 & 15,305 & 7,069 \\
\hline Std. Deviation & & 22,194 & 13,165 & 0,685 & 1,709 & 5,508 \\
\hline Minimum & & 11,79 & 6,00 & 0,34 & 13,43 & 1,55 \\
\hline Maximum & & 99,93 & 71,51 & 3,03 & 19,50 & 23,47 \\
\hline
\end{tabular}

Sumber: data diolah, 2018

Kebijakan dividen diproksikan dengan DPR memiliki nilai rata-rata 55,63\%. Nilai minimum sebesar 11,79\% dimiliki oleh ASII tahun 2017, sedangkan nilai maksimum dimiliki oleh UNVR tahun 2013, yaitu sebesar 99,93\%. Standar deviasi DPR sebesar 22,19\%. Profitabilitas diproksikan dengan ROA memiliki nilai rata-rata $21,03 \%$. Nilai minimum sebesar $6,00 \%$ dimiliki oleh BATA tahun 2017, sedangkan nilai maksimum dimiliki oleh UNVR pada tahun 2013 yaitu sebesar 71,51\%. Standar deviasi untuk ROA sebesar 13,16\%. Leverage diproksikan dengan DER memiliki nilai rata-rata 1,05\%. Nilai minimum sebesar 0,34\% dimiliki oleh SMSM tahun 2017, sedangkan nilai maksimum dimiliki oleh MLBI pada tahun 2014 yaitu sebesar 3.03\%. Standar deviasi untuk DER sebesar 0,68\%. Ukuran perusahaan diproksikan dengan Ln (Total Aktiva) memiliki nilai rata-rata 15,30 rupiah. Nilai minimum sebesar 13,43 rupiah dimiliki oleh BATA tahun 2013, sedangkan nilai maksimum dimiliki oleh ASII pada tahun 2017 yaitu sebesar 19,50 rupiah. Standar deviasi untuk Ln (Total Aktiva) sebesar 
1,71 rupiah. Risiko bisnis diproksikan dengan BRISK memiliki nilai rata-rata 7,07\%. Nilai minimum sebesar 1,55\% dimiliki oleh ASII pada tahun 2016, sedangkan nilai maksimum dimiliki oleh MLBI pada tahun 2013 yaitu sebesar 23,47\%. Standar deviasi untuk BRISK sebesar 5,51\%.

Uji normalitas dilakukan untuk menguji tingkat distribusi data.

Tabel 2.

Hasil Uji Normalitas

\begin{tabular}{ll}
\hline & Unstandardized Residual \\
\hline $\mathrm{N}$ & 30 \\
Asymp. Sig. (2-tailed) & 0,745
\end{tabular}

Sumber: data diolah, 2018

Hasil uji pada Tabel 2 menyatakan bahwa asymp. Sig (2-tailed) adalah $0,745>0,05$ artinya model regresi berdistribusi normal.

Uji multikolinearitas dilakukan untuk mengetahui tingkat korelasi antara variabel bebas penelitian.

Tabel 3.

Hasil Uji Multikolinearitas

\begin{tabular}{|c|c|c|c|}
\hline \multirow[b]{2}{*}{ Model } & & \multicolumn{2}{|c|}{ Collinearity Statistics } \\
\hline & & Tolerance & VIF \\
\hline \multirow[t]{5}{*}{1} & (Constant) & & \\
\hline & ROA & 0,712 & 1,404 \\
\hline & DER & 0,710 & 1,408 \\
\hline & Ln (Total aktiva) & 0,879 & 1,137 \\
\hline & BRISK & 0,699 & 1,430 \\
\hline
\end{tabular}

Sumber: data diolah, 2018

Berdasarkan Tabel 3 nilai tolerance variabel profitabilitas (ROA), variabel leverage (DER), variabel ukuran perusahaan (Ln (total aktiva)), dan variabel risiko bisnis (BRISK) lebih besar dari 0,10 dan nilai VIF lebih kecil dari 10, sehingga dapat dinyatakan model regresi penelitian tidak mengandung multikolinearitas. 
Tresna Dewi Mnune dan Ida Bagus Anom Purbawangsa, Pengaruh Profitabilitas....

Uji autokorelasi bertujuan untuk mengetahui suatu model regresi pada periode $\mathrm{t}$ dengan kesalahan pengganggu pada periode $\mathrm{t}-1$.

Tabel 4.

Hasil Uji Autokorelasi

\begin{tabular}{ll}
\hline Mode & Durbin-Watson \\
\hline 1 & 1,838 \\
\hline Sumber: data diolah, 2018 &
\end{tabular}

Nilai D-W sebesar 1,838 berada diantara $\mathrm{dU}=1.6498$ dan $4-\mathrm{dU}=2,35$ atau $1,6498<1,838<2,35$ sehingga model regresi pada penelitian ini tidak mengandung autokorelasi.

Uji heteroskedastisitas dilakukan untuk melihat ketidaksamaan variance dari residual satu pengamatan ke pengamatan lain pada penelitian

Tabel 5.

Hasil Uji Heteroskedastisitas

\begin{tabular}{|c|c|c|c|c|c|c|}
\hline \multirow{2}{*}{\multicolumn{2}{|c|}{ Model }} & \multicolumn{2}{|c|}{$\begin{array}{l}\text { Unstandardized } \\
\text { coefficients }\end{array}$} & \multirow{2}{*}{$\begin{array}{l}\text { Standardized } \\
\text { coefficients } \\
\text { B }\end{array}$} & \multirow[b]{2}{*}{$\mathrm{t}$} & \multirow[b]{2}{*}{ Sig. } \\
\hline & & $\mathrm{B}$ & Std. Error & & & \\
\hline 1 & (Constant) & 19,650 & 14,198 & & 1,384 & 0,179 \\
\hline & ROA & $-0,074$ & 0,127 & $-0,135$ & $-0,578$ & 0,568 \\
\hline & DER & 1,478 & 2,448 & 0,141 & 0,604 & 0,552 \\
\hline & Ln (Total Aktiva) & $-0,495$ & 0,882 & $-0,118$ & $-0,561$ & 0,580 \\
\hline & BRISK & 0,068 & 0,307 & 0,053 & 0,223 & 0,825 \\
\hline
\end{tabular}

Sumber: data diolah, 2018

Berdasarkan hasil uji heteroskedastisitas, nilai Sig. masing-masing variabel bebas $>5$ persen $(0,05)$ sehingga dapat disimpulkan bahwa model regresi bebas dari heteroskedastisitas.

Analisis linier berganda dilakukan untuk menguji pengaruh variabel bebas terhadap variabel terikat penelitian.

Tabel 6.

Hasil Regresi Linier Berganda $\mathrm{t}$ Nilai Signifikansi 


\begin{tabular}{llll}
\hline Constant) & & 2,561 & 0,017 \\
Profitabilitas $\left(\mathrm{X}_{1}\right)$ & 0,531 & 3,395 & 0,002 \\
Leverage $\left(\mathrm{X}_{2}\right)$ & 0,458 & 2,923 & 0,007 \\
Ukuran perusahaan $\left(\mathrm{X}_{3}\right)$ & $-0,224$ & $-1,589$ & 0,125 \\
Risiko bisnis $\left(\mathrm{X}_{4}\right)$ & $-0,341$ & $-2,161$ & 0,040 \\
\hline R square & & 0,564 \\
Adjusted R Square & & & 0,494 \\
F hitung & & 8,007 \\
Signifikansi & & $0,000^{\mathrm{a}}$ \\
\hline
\end{tabular}

Sumber: data diolah, 2018

Berdasarkan analisis data yang telah ditampilkan pada Tabel 6 maka dapat dibuat persamaan regresi linier berganda sebagai berikut:

$Y=0,531 X_{1}+0,458 X_{2}-0,224 X_{3}-0,341 X_{4}$

Nilai adjusted $\mathrm{R}^{2}$ sebesar 0,494 yang artinya variabel bebas yaitu profitabilitas, leverage, ukuran perusahaan dan risiko bisnis secara serempak mempengaruhi kebijakan dividen sebagai variabel terikat sebesar 49,4 persen, sedangkan sisanya yaitu 50,6 persen dijelaskan oleh faktor-faktor lain diluar variabel penelitian. $\mathrm{F}$ hitung menunjukkan nilai signifikan sebesar $0,000<0,05$; maka dapat disimpulkan bahwa model pada penelitian ini adalah layak.

Berdasarkan hasil pengujian yang dilakukan, profitabilitas secara positif signifikan mempengaruhi kebijakan dividen. Hal ini ditunjukkan oleh hasil uji regresi dimana koefisien regresi 0,531 dengan taraf signifikansi variabel profitabilitas $0,002<0,05$. Hasil penelitian ini menunjukkan bahwa saat profitabilitas perusahaan meningkat maka dividen yang dibayarkan kepada pemegang saham akan meningkat saat profitabilitas perusahaan menurun maka dividen yang dibagikan kepada pemegang saham akan menurun.

Profitabilitas menjadi cerminan tingkat efektifitas pengelolaan perusahaan. Perusahaan yang profitable mengindikasikan bahwa manajemen mampu 
Tresna Dewi Mnune dan Ida Bagus Anom Purbawangsa, Pengaruh Profitabilitas....

mengelola perusahaan dengan baik sehingga mampu meningkatkan kemakmuran bagi pemegang saham. Perusahaan yang berhasil mengumpulkan profit yang besar dinilai mampu meningkatkan pembayaran dividen serta memberikan informasi yang positif kepada pemegang saham. Pemegang saham kemudian akan menilai perusahaan layak untuk dijadikan tempat berinvestasi yang nantinya akan berdampak pada kenaikan harga saham perusahaan.

Signaling theorymenyatakan bahwa sinyal positif yang diberikan oleh perusahaan terkait profitabilitas ini mengandung informasi bahwa perusahaan mampu mengelola perusahaan dengan baik sehingga nantinya mampu menarik minat pemegang saham untuk berinvestasi yang akan berdampak pada peningkatan nilai perusahaan. Pembayaran dividen yang meningkat saat profitabilitas meningkat mampu meminimalkan agency conflict antara pemegang saham dengan perusahaan. Dividen dapat mengurangi asimetri informasi dimana pemengang saham memiliki informasi lebih rendah mengenai perusahaan dibandingkan perusahaan itu sendiri. Peningkatan pembayaran dividen saat profitabilitas perusahaan meningkat memberikan keyakinan bagi pemegang saham bahwa kewenangan yang diberikan kepada manajemen dalam mengelola perusahaan telah dilakukan dengan baik dan perusahaan telah mampu mencapai tujuannya yaitu meningkatkan kemakmuran pemegang saham.

Hasil penelitian ini sejalan dengan hipotesis penelitian pertama $\left(\mathrm{H}_{1}\right)$ yang menyatakan profitabilitas secara positif signifikan mempengaruhi kebijakan dividen serta hasil penelitian dari beberapa peneliti sebelumnya yaitu Thaib \& 
Taroreh (2015), Fillya dkk. (2015), (Hossain et al., 2014), Prawira dkk. (2014), Khan et al. (2013), dan Malik et al. (2013).

Berdasarkan hasil pengujian, leverage secara positif signifikan mempengaruhi kebijakan dividen. Hasil regresi menunjukkan nilai koefisien regresi sebesar 0,458 dengan taraf signifikansi variabel leverage sebesar $0,007<$ 0,05 .

Signaling theory menyatakan bahwa pembagian dividen mengandung suatu sinyal terkait prospek perusahaan kedepannya. Perusahaan yang menurunkan dividen saat laba menurun akan dinilai oleh pemegang saham sebagai suatu informasi negatif bahwa prospek perusahaan akan menurun di masa depan. Jikapembayaran sebelumnya besar maka pembayaran dividen yang diharapkan oleh pemegang saham pada periode selanjutnya harus meningkat. Hal ini akan memicu munculnya pinjaman yang artinya meningkatkan jumlah leverage. Leverage juga dapat dijadikan sebagai alternatif untuk memperkuat stuktur keuangan perusahaan yang akan berdampak pada peningkatan jumlah laba. Laba yang meningkat akan mampu meningkatkan pula proporsi laba yang dibagikan kepada pemegang saham.

Hasil penelitian ini sesuai dengan hipotesis penelitian kedua $\left(\mathrm{H}_{2}\right)$ yang menyatakan leverage secara positif signifikan mempengaruhi kebijakan dividen dan sejalan dengan hasil penelitian yang dilakukan dari Awad (2015), Odawo \& Ntoiti (2015) dan Osegbue et al. (2014)

Berdasarkan hasil pengujian, ukuran perusahaan secara negatif tidak signifikan mempengaruhi kebijakan dividen. Hal ini ditunjukkan oleh hasil uji t 
Tresna Dewi Mnune dan Ida Bagus Anom Purbawangsa, Pengaruh Profitabilitas....

dimana taraf signifikansi variabel ukuran perusahaan sebesar 0,125>0,05 dan nilai koefisien regresi sebesar $-0,224$. Hasil penelitian ini menyatakan bahwa ukuran perusahaan bukan merupakan faktor penentu kebijakan dividen pada perusahaan.

Penyebab tidak signifikannya ukuran perusahaan mempengaruhi kebijakan dividen karena perusahaan dengan ukuran besar maupun kecil memiliki pilihan lain dalam mengembangkan usahanya yaitu dengan melakukan bentuk investasi lain yang lebih menguntungkan. Ukuran perusahaan bukan merupakan faktor penentu besarnya pembayaran dividen kepada pemegang saham karena perusahaan dihadapkan pada banyak pilihan untuk mengembangkan usahanya dan menarik minat pemegang saham dalam berinvestasi. Peluang bisnis yang dilihat oleh perusahaan membuat perusahaan lebih mengutamakan untuk menahan laba untuk membiayai investasi yang lebih menguntungkan sehingga nantinya keuntungan yang didapat oleh perusahaan akan lebih besar.

Semakin tinggi jumlah laba ditahan maka dividen yang dibayarkan kepada pemegang saham akan rendah. Pemegang saham menilai keputusan yang diambil oleh perusahaan yang lebih mengutamakan pengembangan usaha melalui investasi lain dibandingkan membayarkan dividen sebagai suatu sinyal bahwa perusahaan memiliki prospek yang baik kedepannya karena perusahaan mampu melihat peluang investasi lain yang nantinya mampu meningkatkan keuntungan bagi pemegang saham. Hasil penelitian ini tidak sesuai dengan hipotesis penelitian ketiga $\left(\mathrm{H}_{3}\right)$ yang menyatakan ukuran perusahaan secara positif signifikan mempengaruhi kebijakan dividen. Namun hasil penelitian ini sejalan dengan hasil 
penelitian yang dilakukan oleh Iswara (2017), Nidya \& Titik (2015) dan Dada et al. (2015).

Berdasarkan hasil pengujian, risiko bisnis secara negatif signifikan mempengaruhi kebijakan dividen. Hal ini ditunjukkan oleh hasil uji t dimana taraf signifikansi variabel risiko bisnis sebesar $0,040<0,05$ dan nilai koefisien regresi sebesar -0,341. Hasil penelitian ini menunjukkan bahwa semakin meningkat risiko bisnis maka dividen yang dibayarkan akan menurun.

Perusahaan dengan risiko bisnis tinggi memiliki kemungkinan ketidakmampuan dalam membiayai operasional perusahaan yang akan menyebabkan laba menurun. Perusahaan dengan risiko bisnis yang tinggi juga memiliki kesulitan untuk memperoleh pinjaman berupa hutang karena kreditur tidak yakin bahwa perusahaan mampu membayar hutang dengan melihat tingginya risiko yang dimiliki perusahaan. Hal ini membuat perusahaan berusaha untuk menguatkan kondisi keuangan internal dengan mempertahankan laba dalam bentuk laba ditahan sebagai sumber pendanaan internal. Perusahaan akan berusaha untuk memaksimalkan segala usaha dalam hal pendanaan untuk meminimalisir risiko bisnis tersebut. Hal ini menyebabkan perusahaan akan lebih mengutamakan untuk menahan laba dalam rangka menguatkan struktur modal dibandingkan membayarkan dividen. Perusahaan dengan risiko bisnis yang tinggi mengharuskan manajemen berusaha untuk menguatkan struktur modal terlebih dahulu melalui pemanfaatan laba karena penggunaan leverage tidak dapat diharapkan. Investasi pada sector lain juga merupakan salah satu cara untuk memperoleh laba sehingga perusahaan lebih mengutakan untuk menginvestasikan 
Tresna Dewi Mnune dan Ida Bagus Anom Purbawangsa, Pengaruh Profitabilitas....

dananya pada sector lain dibandingkan membayar dividen. Semakin meningkatnya jumlah laba ditahan dan penggunaan laba untuk investasi maka akan menurunkan jumlah dividen yang akan dibagikan kepada pemegang saham. Oleh sebab itu sebaiknya perusahaan yang berisiko tinggi menetapkan dividen yang rendah sebagai batas normal sehingga jika terjadi laba menurun di masa depan tidak terjadi penurunan dividen dari batas normal atau pemotongan dividen.

Hasil penelitian ini sesuai dengan hipotesis penelitian keempat $\left(\mathrm{H}_{4}\right)$ yang menyatakan risiko bisnis berpengaruh negatif dan signifikan terhadap kebijakan dividen serta penelitian terdahulu yang dilakukan olehForti et al. (2015), Osegbue et al. (2014) dan Al-khadhiri (2013).

\section{SIMPULAN DAN SARAN}

Simpulan dari hasil penelitian dan pembahasan yang telah dilakukan mengenai pengaruh profitabilitas, leverage, ukuran perusahaan dan risiko bisnis terhadap kebijkan dividen adalah sebagai berikut: 1) Profitabilitas berpengaruh positif dan signifikan terhadap kebijakan dividen pada perusahaan manufaktur yang terdaftar di BEI periode 2013-2017. 2) Leverage berpengaruh positif dan signifikan terhadap kebijakan dividen pada perusahaan manufaktur yang terdaftar di BEI periode 2013-2017. 3) Ukuran perusahaan berpengaruh negatif dan tidak signifikan terhadap kebijakan dividen pada perusahaan manufaktur yang terdaftar di BEI periode 2013-2017. 4) Risiko bisnis berpengaruh negatif dan signifikan terhadap kebijakan dividen pada perusahaan manufaktur yang terdaftar di BEI periode 2013-2017. 
Berdasarkan hasil penelitian yang telah dilakukan saran yang dapat diberikan adalah sebagai berikut: 1) Pihak manajemen dalam menentukan kebijakan dividen diharapkan mempertimbangkan mengenai faktor profitabilitas, leverage, ukuran perusahaan dan risiko bisnis sehingga kebijakan dividen yang diambil sesuai dengan tujuan perusahaan dan mampu meningkatkan keuntungan bagi perusahaan. 2) Pemegang saham dalam memutuskan untuk melakukan investasi pada suatu perusahaan diharapkan mempertimbangkan profitabilitas, leverage, dan risiko bisnis dari perusahaan karena faktor ini yang secara signifikan mempengaruhi pembayaran dividen sehingga nantinya tingkat pengembalian yang diterima oleh pemegang saham sesuai dengan investasi yang dilakukan pada perusahaan. 3) Penelitan selanjutnya diharapkan dapat mempertimbangkan variabel lain seperti kepemilikan institusional, likuiditas, pajak, peluang investasi dan sebagainya serta lingkup subjek penelitian yang lebih luas.

\section{REFERENSI}

Ahmad, G. N., Dewi, F. A., \& Umi, M. (2016). The Influence of Market to Book Value, Annual Tax, and Risk Towards Dividend Policy in Banking Company Listed in Indonesia Stock Exchange (IDX) Period 2010-2014. Jurnal Riset Manajemen Sains Indonesia (JRMSI), 7(1), 157-175.

Al-khadhiri, A. (2013). Determination of Dividend Policy: The Evidence from Saudi Arabia. International Journal of Business and Social Science, 4 (1), hal. 181-192.

Amah, N. (2012). Faktor-faktor yang Mempengaruhi Dividend Policy Perusahaan GoPublic di Indonesia. Jurnal Akuntansi Dan Pendidikan, 1(1), 45-55.

Arjana, I. P. P. H., \& Suputra, I. D. G. D. (2017). Pengaruh Profitabilitas, Leverage, Ukuran Perusahaan dan Corporate Social Responsibility Pada Kebijakan Dividen. E-Jurnal Akuntansi, 21(3), 2021-2051. 
Asad, M., \& Yousaf, S. (2014). Impact of Leverage on Dividend Payment Behavior of Pakistani Manufacturing Firms. Business and Economics, 6(2), 216-221.

Awad, B. (2015). Determinants of Dividend Policy in Kuwait Stock Exchange. International Journal of Business And Management Review, 3(7), 72-78.

Brigham, Eugene F. and Houston, Joel F. (2011). Dasar-Dasar Manajemen Keuangan. (Edisi Sebelas, Buku Pertama). Jakarta: Salemba Empat.

Dada, F. B., Malomo, E., \& Ojediran, S. (2015). Critical Evaluation of the Determinants of Dividend Policy of Banking Sector in Nigeria. International Journal of Economics, Commerce and Management, 3(2), 111.

Demirgünescedil; K. (2015). Determinants of Target Dividend Payout Ratio: A Panel ARDL Analysis. International Journal of Economics and Financial Issues, 5(2), 418-426.

Devi, N. P. Y., \& Erawati, N. M. A. (2014). Pengaruh Kepemilikan Manajerial, Leverage, Dan Ukuran Perusahaan Pada Kebijakan Dividen Perusahaan Manufaktur. Jurnal Akuntansi, 9(3), 709-716.

Epayanti, A., \& Yadnya, I. P. (2014). Pengaruh Ukuran Perusahaan dan Risiko Bisnis Terhadap Profitabilitas Serta Kebijakan Dividen. E-Jurnal Manajemen Universitas Udayana, 3(12), 3488-3502.

Fillya, A., Ervita, S., \& Rini, A. (2015). Pengaruh Likuiditas, Leverage, Profitabilitas, Ukuran Perusahaan dan Growth Terhadap Kebijakan Dividen. E-Jurnal Akuntansi, 1(1), 1-13.

Forti, C. A. B., Peixoto, F. M., \& Alves, D. L. e. (2015). Determinant Faktors of Dividend Payments in Brazil. Revista Contabilidade \& Finanças, 26(68), 167-180.

Gitosudarmo, Indriyo dan Basri. (2008). Manajemen Keuangan. Yogyakarta: BPFE.

Gusni. (2017). The Determinants of Dividend Policy: A Study of Financial Industry in Indonesia. Jurnal Keuangan Dan Perbankan, 21(4), 562-574.

Harahap, Sofyan Syafri. (2013). Analisis Kritis atas Laporan Keuangan. Jakarta: PT. Raja Grafindo Persada.

Horne, James C. Van dan John M Wachowicz, Jr. (2012). Prinsip-prinsip Manajemen Keuangan. (Edisi Duabelas, Buku 2). Jakarta: Salemba Empat. 
Hossain, F., Sheikh, R., \& Akterujjaman, S. M. (2014). Impact of Firm Specific Faktors on Cash Dividend Payment Decisions : Evidence from Bangladesh Hossain , Sheikh \& Akterujjaman. International Review of Business Research Papers, 10(2), 62-80.

Husnan, Suad dan Pujiastuti. (2012). Dasar-dasar Manajemen Keuangan. Yogyakarta: UPP AMP YKPN.

Iswara, P. W. (2017). Pengaruh Rasio Likuiditas, Rasio Profitabilitas, Rasio Leverage, Ukuran Perusahaan, dan Aset Growth terhadap Kebijakan Dividen (Studi Kasus pada Perusahaan Industri Manufaktur Sub Sektor Makanan dan Minuman yang terdaftar di Bursa Efek Indonesia Periode. Jurnal Bisnis Dan Politeknik NSC Surabaya, 4(1), 33-47.

Kaźmierska-Jóźwiak, B. (2015). Determinants of Dividend Policy: Evidence from Polish Listed Companies. Procedia Economics and Finance, 22(26), 473477.

Khan, W. ., Naz, A. ., Khan, W. ., Khan, Q. ., Khan, T. ., \& Mughal, I. (2013). Impact assessment of financial performance and leverage on dividend policy of pakistan chemical and pharmaceutical industries. Middle East Journal of Scientific Research, 16(10), 1376-1382.

KHAN, W., \& ASHRAF, N. (2014). In Pakistani Service Industry: Dividend Payout Ratio as Function of some Faktors. International Journal of Academic Research in Accounting, Finance and Management Sciences, 4(1), 390-396.

Komrattanapanya, P., \& Suntraruk, P. (2014). Faktors Influencing Dividend Payout in Thailand: A Tobit Regression Analysis. International Journal of Accounting and Financial Reporting, 3(2), 255.

Maldajian, C., \& El Khoury, R. (2014). Determinants of the Dividend Policy: An Empirical Study on the Lebanese Listed Banks. International Journal of Economics and Finance, 6(4), 240-256.

Malik, F., Gul, S., Khan, M. T., \& Rehman, S. U. (2013). Faktors Influencing Corporate Dividend Payout Decisions of Financial and Non-Financial Firms. Research Journal of Finance and Accounting, 4(1), 2222-2847.

Nidya, A. P., \& Titik, F. (2015). Pengaruh Debt to Equity Ratio, Profitabilitas, Growth, dan Ukuran Perusahaan Terhadap Kebijakan Dividen (Studi Kasus Pada Perusahaan Manufaktur yang Terdaftar di Bursa Efek Indonesia). EProceeding of Management, 2(1), 488-496.

Odawo, C., \& Ntoiti, J. (2015). Determinants of dividend payout policy in public 
Tresna Dewi Mnune dan Ida Bagus Anom Purbawangsa, Pengaruh Profitabilitas....

Ltd banks in Kenya: a case study of CFC Stanbic Bank. The Strategic Journal of Management, 2(54), 182-191.

Osegbue, I. F., Ifurueze, M., \& Ifurueze, P. (2014). An analysis of the relationship between dividend payment and corporate performance of Nigerian banks. Global Business and Economics Research Journal, 3(2), 75-95.

Prawira, I. Y., Dzulkirom, M., \& Endang, M. G. W. (2014). Pengaruh Leverage, Likuiditas, Profitabilitas, dan Ukuran Perusahaan Terhadap Kebijakan Deviden (Studi Pada Perusahaan Perbankan Yang Terdaftar di Bursa Efek Indonesia Tahun 2010 - 2013). Jurnal Administrasi Bisnis (JAB), 15(1), 17.

Putri, I Gusti Ayu Made Asri Dwija dan I Gusti Ketut Agung Ulupui. (2017). Pengantar Corporate Governance. Denpasar: Sastra Utama.

Raipassa, C., Parengkuan, T., \& Saerang, I. (2015). Pengaruh Rasio Profitabilitas, Likuiditas, Dan Leverage Terhadap Dividen Payout Ratio Pada Perusahaan Farmasi Yang Terdaftar Di Bursa Efek Indonesia. Jurnal Berkala Ilmiah Efisiensi, 15(5), 610-621.

Safrida, E. (2014). Profitabilitas Dan Pertumbuhan Perusahaan Terhadap Kebijakan Deviden Pada Perusahaan Manufaktur Di Indonesia. Jurnal Riset Akuntansi Dan Keuangan Program Studi Akuntansi Fakultas Pendidikan Ekonomi Dan Bisnis Universitas Pendidikan Indonesia, 2(1), 289-299.

Sartono, Agus. (2010). Manajemen Keuangan Teori dan Aplikasi. (Edisi Empat). Yogyakarta: BPFE.

Setiawati, L. W., \& Yesica, L. (2014). Analisis Pengaruh Pertumbuhan Perusahaan, Kebijakan Utang, Collateralizable Asets, dan Ukuran Perusahaan Terhadap Kebijakan Dividen Pada Perusahaan Manufaktur Yang Terdaftar di Bursa Efek Indonesia Periode 2012-2014. Jurnal Akuntansi, 1(1), 52-82.

Subramanyam, KR dan John, J. Wild. (2010). Analisis Laporan Keuangan (Edisi Sepuluh). Jakarta: Salemba Empat.

Sudana, I Made. (2011). Manajemen Keuangan Perusahaan: Teori dan Praktek. Jakarta: Penerbit Erlangga.

Sugiyarso, G dan Winarni, F. (2005). Manajemen Keuangan. Yogyakarta: Media Pressindo.

Tandelilin, Eduardus. (2010). Portofolio dan Investasi: Teori dan Aplikasi. Yogyakarta: Kanisius. 
E-Jurnal Manajemen, Vol. 8, No. 5, 2019 : 2862-2890

Thaib, C., \& Taroreh, R. (2015). Pengaruh Kebijakan Hutang dan Profitabilitas Terhadap Kebijakan Dividen. Jurnal EMBA, 3(4), 215-225.

Wiagustini, Ni luh Putu. (2010). Dasar-Dasar Manajemen Keuangan. Denpasar: Udayana University Press.

Yusof, Y., \& Ismail, S. (2016). Determinants of dividend policy of public listed companies in Malaysia. Review of International Business and Strategy, 26(1), 88-99. 